\title{
Humanitarian Interventions as Practices of Statecraft: Re-Crafting State Sovereignty in Refugee Crises
}

\author{
Nevzat Soguk
}

\begin{abstract}
This study argues that humanitarian interventions are not undertaken merely to alleviate the sufferings of people under duress such as refugees. Beyond humanitarianism, they are activities of statist governance-practices of statecraft oriented to re-articulate and re-craft state sovereignty and the hierarchy it signifies, that is, the hierarchy of citizen/nation/state, not only as natural but also as necessary to the peaceful, stable, and secure organization of local and global politics. Inasmuch as humanitarian interventions target refugees as objects of intervention, they appropriate refugees to the task of statecraft; refugees become not only the manifestation of the difficulties for the sovereign state, but also the site of statist practices, which, attendant upon refugees, endeavour continuously to re-articulate the state-centric imagination of life possibilities in local and global interactions. In the process, humanitarianism is typically subordinated to the contingencies of statism in the late 20th Century.
\end{abstract}

\section{Précis}

Cet article avance l'hypothèse que l'on ne pursuit pas d'intervention humanitaire pour alléger la souffrance des peuples sous détresse, commes les réfugiés; plutôt, une telle intervention reflet l'action étatique, destinée à ré-artriculer et ré-monter la souveraineté. Elle signifie la hiérarchie du citoyen/État-nation comme naturelle et intégrale à l'organisation paisible, stable et sûre à la fois au plan local et au global. En tant que l'intervention humanitaire choisit les réfugiés comme cible de l'action, les réfugiés

Dr. Nevzat Soguk is an Assistant Professor in the Department of Political Science at the University of Hawaii at Manoa. deviennent eux-mêmes l'objet des ruses de politique. Ils représentent donc non seulement une difficulté pour l'état souverain mais aussi l'objet continu de la pratique étatique. L'état tient à ré-articuler l'imagination état-centrique $d u$ possible au plan local ainsi que global. Surces entrefaites, $l^{\prime}$ action humanitaire devient assujettie typiquement aux fortunes étatiques $d u$ fin-de-20e siècle.

"The subject of refugees and displaced persons is at the cutting edge of international concern today not only because of its humanitarian significance, but also because of its impact on peace, security, and stability."

Sadako Ogata, UN. High Commissioner for Refugees, 1994

\section{Of Practical Interfaces: Humanitarian Intervention, Statecraft, and Refugees}

In recent years, the study of humanitarian interventions has proliferated. ${ }^{1}$ This proliferation has come on the heels of a number of catastrophic developments which, in response, triggered "humanitarian interventions," purportedly undertaken to stop or alleviate massive human sufferings resulting from these catastrophic developments. Intervention in Iraqi Kurdistan, the former Yugoslavia, Somalia, and Rwanda, are the most conspicuous, precedent setting examples of humanitarian interventions.

While the recent proliferation of interventions has revived the discussions around such issues as the legality, efficacy, and ethics of humanitarian intervention, it is fair to say that of all the issues under consideration, the studies on humanitarian interventions concentrate most on the perennial issue of state sovereignty, regarding sovereignty as the generative and operative principle underly- ing the organization of global politics in the contemporary world. Specifically, they focus on and examine the implications of humanitarian interventions for the principle and practices of state sovereignty.

Studying humanitarian interventions in the junctures of worldwide economic and geopolitical shifts, a considerable number of these studies construe humanitarian interventions as markers of an historic erosion of state sovereignty as a principle and practice of political organization in life across the globe. This construal is positioned in the larger globalizing and transnationalizing landscape of life where historically peculiar relations and institutions of state sovereignty, under pressure from globalizing developments, are seen to melt into a "transnational air." "A number of developments," writes Arnison, for instance:

are chipping away at sovereignty. National borders have become increasingly porous as trade, mass communications, and environmental degradation hasten global interdependence. The growth of international human rights law during the last four decades has made important inroads into sovereignty ... The citadel of sovereignty is beginning to $\mathrm{crack}^{2}$

"The world community," Lewis adds, "has broken new ground in international law, slowly laying the foundations of a new right of outside intervention in the formerly sacrosanct internal affairs of sovereign states. ${ }^{3}$ Concurring with the general observation, ${ }^{4}$ Weiss and Minear state that:

as the world moves from the Cold War to the post-Cold War era, sovereignty as traditionally understood is no longer sacrosanct. The age-old balance between state assertions of sovereignty and international ex- 
pressions of solidarity with those who suffer has begun to shift perceptibly in favour of those who are in need. ${ }^{5}$

In sum, in the larger global landscape, to many observers humanitarian interventions signify yet another dimension of the "erosion" of state sovereignty.

While these commentaries surely represent a forceful and even an authoritative line of thinking about the implications of interventions for state sovereignty, it is possible to argue that, perhaps, this forceful line of thinking does not fully represent the polymorphic implications of interventions for state sovereignty. In fact, contrary to the foregoing reading, I want to argue that the so-called humanitarian interventions could be seen to work less to undermine and more to foster state sovereignty and the hierarchy it signifies-the hierarchy of citizen/nation/ state not only as natural but also as necessary to the peaceful, stable, and secure organization of local and global politics. In the globalizing crucible of the late 20th Century, humanitarian interventions could indeed be seen as one of many kinds of strategies employed to re-articulate and to refashion the statist governance.

In other words, it is possible to see humanitarian interventions as intergovernmentally orchestrated sets of practices that do more than attend to the problem of humanitarian crises. It is possible to see them, to use Foucauldian terminology, as activities of problematizations ${ }^{6}$ that work to recover or recuperate state sovereignty in the face of specific historical challenges that call into question the very viability of state sovereignty as the operative principle in national and international governance.

This is not to suggest that "humanitarian interventions" are not "humanitarian" at all. ${ }^{7}$ Rather, it is to suggest that in the so-called humanitarian interventions, humanitarianism is subordinated to the exigencies of statism. Beyond humanitarianism are intergovernmentally orchestrated practices of statecraft which, while purportedly oriented to alleviate human suffering in the hands of maverick states, work also to re-articulate the peculiar images, identities, relations, and institutions that signify the citizen/nation/ state hierarchy as the necessary foundational hierarchy underlying the modern territorial state system.

Admittedly, it is rare that one would encounter an account of humanitarian interventions in precisely these terms. However, it might be possible to glimpse such recuperative, stateoriented dynamics of humanitarian interventions by looking into the intergovernmental discourse on humanitarian interventions, particularly in those instances of interventions triggered in response to massive refugee events. The interventions in Northern Iraq, Somalia, and Bosnia are such instances at which the interventions meanings of the citizen/nation/state hierarchy?

I believe that, together, these questions help point to the linkages between humanitarian interventions in refugee crisis and the artifice of statecraft in the late 20th Century. To illustrate, I turn to a specific intervention case that has fuelled the humanitarian intervention discourse in an unprecedented fashion. It is the intervention in Iraq in April 1991 in the aftermath of the Gulf War.

\section{Humanitarian Interventions, Refugees, and Statecraft: \\ Kurdish Refugee Crisis in Point}

Humanitarian Crisis Scene: The drama which struck northern Iraq in early April will always mark refugee history. The unforeseen consequences of the [Gulf war], the violent events

\section{In the globalizing crucible of the late 20th Century, humanitarian interventions could indeed be seen as one of many kinds of strategies employed to re-articulate and to re-fashion the statist governance.}

came on the heels of massive internal and international human displacement. Here, I argue that examination of the discourse of interventionist humanitarianism in such massive refugee events evinces the practical underpinnings that link humanitarian intervention, state sovereignty, and statecraft. Such an examination is guided by a number of questions:

How, in those instances, was the problem of crisis articulated in terms of refugee event? What was posited, included and what was questioned and excluded in the articulation of the problem? What was pronounced and what was obscured? How were the refugee events problematized in a Foucauldian sense as events of humanitarian crisis demanding response, thus to enable the undertaking of humanitarian interventions? How, in other words, does the refugee get constituted as an object of humanitarian interventions? And what does the object, once problematized, represent/signify relative to the posited relations, institution, and which broke out in the provinces of Iraqi Kurdistan, followed by the desperate flights of hundreds of thousands of people, deeply shocked public opinion. A succession of bewildering figures flashed over the teletexts: 10,000 displaced persons, then $30,000,50,000,500,000$, one million, perhaps more, moving in hordes toward neighbouring countries. (Refugees , 12 June 1991)

Humanitarian Intervention Scene: On April 5, 1991, the UN Security Council, in an unprecedented fashion, overrode the Iraqi government's assertion of sovereignty, which had been used to deny humanitarian access to Kurdish refugees. Viewing mass upheaval as a threat to international security, the Security Council in Resolution 688 insisted "that Iraq allow immediate access by international humanitarian organizations to all those in need of assistance in all parts of Iraq. The subsequent creation by American, British, French, and Dutch Marines of safe havens for the Iraqi Kurds within north- 
ern Iraq may prove to have been the a turning point in the evolution of global humanitarian ethics. Certainly, it suggests what an aroused global community can do when denied access to civilians imperilled within a country. (Minear and Weiss 1992, 1-2, emphasis added.)

It is generally accepted that UN Security Council Resolution 688 of April 5, 1991, paved the way for and justified the allied intervention in Iraq to save the Kurds, for it was oriented to provide humanitarian assistance to Kurdish refugees in the face of Iraqi defiance. Many in policy-making and academic circles, as well as in the popular media, argued that the intervention was indeed a humanitarian intervention. $^{8}$

The President of the United States, George Bush, echoed a similar logic, arguing that in the face of humanitarian crisis manifest in excessive human suffering, as in northern Iraq, victims must be helped even, if necessary, without the consent of the sovereign. "Some, he said, might argue that this is an intervention into the internal affairs of Iraq, but I think the humanitarian concern, the refugee concern is so overwhelming that there will be a lot of understanding about this." ${ }^{\prime 9}$ In the US Congress, the Chairman of the House Foreign Affairs Committee said: "We are intervening in the sovereignty of Iraq, I think for good reason here, to help these Kurdish people ..."10 The French Ambassador to the UN, JeanBernard Marimee offered a concurring reason for the humanitarian intervention in Iraq: "Definitely, the idea is beginning to prevail that sovereignty is not a sufficient reason for a sovereign state to kill without any limitation its citizens, and that the international community has a sort of moral right to intervene."11

The Security Council Resolution 688 is worth quoting at length because it is representative of the specific vocabularies, significations, and classifications through which humanitarian interventions are written, talked about, circulated, and assigned contingent referentiality in wider fields of activity. It is through similar vocabularies that humanitarian interventions are attributed specific cultural, political, and legal meanings and identities which enable many naturally and effortlessly to say, "what took place was an humanitarian intervention."

THE SECURITY COUNCIL, MIND-

FUL of its duties and its responsibilities under the charter of the United Nations for the maintenance of international peace and security ...

GRAVELY CONCERNED by the repression of the Iraqi civilian population in many parts of Iraq, including most recently in Kurdish populated areas which led to a massive flow of refugees towards and across international frontiers and to cross border incursions, which threaten international peace and security in the region,

DEEPLY Disturbed by the magnitude of human suffering involved ...

REAFFIRMING the commitment of all member states to the sovereign, territorial integrity and political independence of Iraq and of all states in the area ...

CONDEMNS the repression of the Iraqi civilian population in many parts of Iraq, including most recently in Kurdish populated areas, the consequences of which threaten international peace and security in the region;

DEMANDS that Iraq, as a contribution to removing the threat to international peace and security in the region, immediately end this repression and expressing the hope in the same context that an open dialogue will take place to ensure that the human and political rights of all Iraqi citizens are respected;

INSIST that Iraq allow immediate access by international humanitarian organizations to all those in need of assistance in all parts of Iraq, and to make available all necessary facilities for their operations ...

While in the most political and popular accounts, we are left with the impression that humanitarian interventions take place in order to put an end to human suffering when, in the words of the French Ambassador, "a state [starts] killing without limitations," the opening paragraph of the resolution articulates a different reason for the intervention. This is significant, for the that paragraph frames the normative policy context, pointing to the larger issues at stake- "the maintenance of international peace and security." The maintenance of international peace and security, not human suffering, we are thus instructed, is the prevailing concern in the minds of the council members.

Clearly, the opening paragraph of the resolution betrays the efforts to otherwise frame the intervention primarily, if not exclusively, in terms of human rights. Although we are repeatedly and patiently instructed, say, by George Bush or the French Ambassador, to believe that the intervention was driven merely by a desire to save lives, the official justificatory discourse suggests a different concern animating the intervention efforts.

The object of the intervention, in this discourse, is not human-beings as victims of a state gone aberrant. Rather, the object of intervention, the resolution instructs us, is human-beings as refugees, namely, citizens gone aberrant to become refugees. The object is not refugees as human-beings, but human-beings as refugees, in the words of the resolution, "flowing towards and across international borders and [effecting] cross-borders incursions, which threaten international peace and security in the region." The object of intervention is, in most simple terms, refugees problematized as threats to international peace and security. It is the threat to international peace and security of refugee movements that the Council is "gravely concerned" about, especially considering the transborder/transversal implications of refugee movements in the region.

The problem-the humanitarian crisis-is defined not so much in terms of human beings in need of relief and comfort as in terms of refugees as constituting a problematic category of people-those who lack the qualities of the proper subjectivity of the state, 
the citizen-subjects. Similarly, one could suggest, the problem is defined not so much in terms of a state gone aberrant, but in terms of the product of state activities, namely, in terms of refugees as an aberrant category of people that must be dealt with.

Frelick offers a corroborating interpretation. ${ }^{12}$ Frelick's analysis is instructive as intimated in the title of his article, "The False Promise of Operation Provide Comfort." "The resolution," Frelick writes, referring to resolution 688, "is important both for what it says and for what it does not say. It frames its condemnation of Saddam Hussein's repression not in terms of human rights violations committed against Iraqi citizens inside Iraq, but rather in terms of the massive flow of refugees toward and across international frontiers caused by the repression." ${ }^{13}$ The influential Turkish columnist Ali Sirmen also zeroes in on the Kurdish refugee bodies, suggesting that they constitute a security problem for the whole region. He wrote:

There is another issue to which more attention needs to be given. The problem of the refugees, who were uprooted and driven to the borders by the pressures from the government of Saddam, is no more the internal affairs of Iraq exclusively, but has become an international problem that bears on the internal stability of many regional countries and, by implication, on the stability of the whole region. Turkey has successfully defended this position in the United Nations and, with support from France, facilitated the adoption of Resolution 688. ${ }^{14}$

Clearly, it is the citizens that go aberrant, becoming refugees, as a result of events and occurrences beyond their control, not the state. Although the state violates the compact, it still remains a state, as it were, already there, already established with and through prevailing relations and institutions, and already empowered to speak and be heard. This construction of agency is demonstrable in the language of Resolution 688. What the resolution calls for, or, in this case, asks from Iraq, "as a contribution to removing the threat to international peace and security, is [simply] to end the repression, open dialogue," and recognize that its activities of statecraft to effect its sovereign power in the territorial locale Iraq have to be carefully regimented lest they endanger, as they do now, the activities of statecraft in other locales and threaten international peace and security.

In fact, Iraq was an integral part of the regimentation of the problem pragmatically, symbolically, and rhetorically in terms of the conventional territorializing discourse of international relations. The United Nations and individual governments, including the permanent members of the UN Security Council, as well as Turkey, went to great lengths to incorporate Iraq into the process of dealing with refugees. While the parties expressed outrage towards one another publicly through diplomatic and military channels, they have collaborated extensively to smooth out the refugee problem. On April 18, 1991, for example, the UN, with the explicit support of and even prodding from the allied powers, signed a 21 point "Memorandum of Understanding" 15 with the Iraqi government, which affirmed Iraqi sovereignty over all humanitarian activities in all of Iraq (which also included the Allied operations in the so called "Safe Haven" in northern Iraq without making any specific reference to them). In a minimal sense, the Memorandum had a symbolic as well as rhetorical utility for projecting (imagining) Iraqi sovereignty as the principle regulating life activities in the country (when that was clearly not the case) and Iraq as a territorially bound, exclusive sovereign space for the habitation of the Iraqi citizens-a sovereign space separate from Turkey and Iran. ${ }^{16}$

In essence, the problem of humanitarian crisis in the Kurdish episode is defined in terms of a figure of aberrance-the refugee-recognized across the world negatively relative to the positive, constitutive hierarchy of the citizen/nation/state as the hierarchy underlying the modern territorial state system. Refugees, conceptualized negatively as figures of lack relative to the posited qualities of the citizen, stand at the heart of the construction of the problem of this humanitarian crisis.

In the resolution, as in other instances of dealing with the refugee problem, the prescribed solutions lie in the recovery of the potential citizen in the refugee by re-entering the refugee into the citizen/nation/state hierarchy. In real terms, that means the establishment of not just the refugee's territorial ties with the national community or the country of origin from which the refugee comes, but, more importantly the refugee's ties with the state which is the legal representative and protector of the national community. Accordingly, writing in the Turkish daily, Cumhuriyet, Kirisci, an academic with close ties to the Turkish foreign ministry, identified "repatriation" as the best solution to the Kurdish refugee problem. "The best solution to the problem," Kirisci wrote:

is to create the environment which would be conducive to returning the refugees to Iraq on their own cognizance, an objective for which Turkey needs urgently to work through diplomatic channels. This objective may yet necessitate a pragmatic approach towards the Iraqi government. If a political solution that will facilitate the refugees' return to their homes is not found soon, Kurdish refugees may find themselves in the same circumstances as the Palestinians who have been living in refugee camps for the last 43 years. ${ }^{17}$

Then the USSR's Ambassador to Turkey, Albert Cernisev, argued similarly in an interview with a Cumhuriyet reporter:

There is no alternative for the Kurdish refugees but to return to their homes. What is of crucial importance is the question of confidence and trust between those who left their homes and Baghdad. This confidence could be rebuilt in time. ${ }^{18}$

To exist again, the ambassador asserted, the refugees must return "home"; they must have their territorial ties re-established with the community of citizens represented and 
protected by the Iraqi state. What is clear here is that specific problematizations of the refugee in humanitarian crises affirm not just the primacy and normalcy of the subjectivity of the citizen, but also its absolute necessity for the possibility of living at "home" in peace. It is only the citizen-subject that can exist properly, but in a community of citizens made possible only within the spatial borders of the sovereign state. Therefore, refugee problematizations in humanitarian crises work to affirm not just the primacy and normalcy but also the absolute necessity of a specific form of political community, the domestic community of citizens represented and protected by the

identities. They are lent to the task of statecraft in precisely those times when the perennial projects of statecraft-borders, citizen, domestic community, sovereign territory, etc.-are called increasingly into question in the crucible of transversal political and economic occurrences. ${ }^{20}$

Huysmans ${ }^{21}$ writes instructively, speaking of "securitization of migration" in general as a "stabilizing strategy" of the state: "In the contemporary [world], the nation-state is no longer taken for granted. In the struggle for the nation-state, a highly securitized migration could well be a strategy for reaffirming the identity of the state." Hoffman concurs while also introduc-

\section{In essence, the problem of humanitarian crisis in the Kurdish episode is defined in terms of a figure of aberrance-the refugee- recognized across the world negatively relative to the positive, constitutive hierarchy of the citizen/nation/state as the hierarchy underlying the modern territorial state system.}

sovereign state. As Ambassador Cernisev intimates, one must not even think that there could be an alternative to territorially bound homes.

The Kurdish refugee crisis is uniquely enabling in allowing one to focus on the linkages between refugees and the security issues in constructing humanitarian interventions. Huysman calls this ever-intensifying strategy of "writing" the refugee through the semiotics of security images and identities the "securitization" ${ }^{\prime 19}$ of the refugee whereby the refugee images and identities are encoded and re-coded through the extant lexicon of security notions and concerns, and the re-coded refugee images and identities work in turn to re-conceptualize the security images, identities, and subjectivities, in this case the images, identities, and subjectivities centered around the sovereign state.

The crucial effect here is not just that the refugee images are encoded through the locutions of security concerns, but that these images, once encoded with specific statist security images and identities, are lent to the reconstitution of statist images and ing the notion of intervention into the debate. It might be possible, he suggests, to see the acts of intervention (or nonintervention) as the affirmation of existing boundaries and their constitution. ${ }^{22}$ Ashley argues that all those activities have to be subsumed under the sign of modern statecraft by which the identities and subjectivities of the modern state are produced and stabilized at any particular time in history, including times of uncertainties and crises. "Modern statecraft," Ashley writes,

works to fabricate and institutionalize a new problematization that incites and conditions people's attention to those emergent uncertainties, ambiguities and indeterminancies that put in doubt the identity of 'man in domestic society.' In the same stroke, it fashions, exemplifies, and offers patient instruction in an aesthetics of existence whose values and criteria dispose people both (a) to understand these uncertainties as problems and dangers that occupy some region of 'anarchy' external to the domestic time and place of the sovereign 'man' and (b) to willingly support a state, its law, its tech- nologies of violence, its administrative resources and its international regimentation of economic, environmental [and political] policies as means by which the problems and dangers of 'anarchy' might be solved or brought under control in the name of 'man.' ${ }^{23}$

Refugees, securitized in/through humanitarian interventions, stand as objects of statecraft. They stand as objects of intervention useful to the task of statecraft. They stand, in other words, as objects of humanitarian interventions as practices of statecraft. These practices are oriented not so much to care for the needy, the displaced, the one in crisis, the refugee, as to produce and privilege the practical/ representational sources of the state's claim to territorial sovereignty, namely the citizen to which the state owes its raison d'etre.

In this sense, refugees manifest the difficulties of the sovereign state, or state sovereignty. Paradoxically, however, attendant through humanitarian interventions, refugee bodies also work as resources for statecraft. Actual refugee bodies (i.e., the Kurdish refugees who straddled the borders of Turkey, Iran, and Iraq in April of 1991) work as concrete, material, and indeed, as corporeal links between the principle-the claim-of state sovereignty articulated to the citizen/nation/state hierarchy and practices of statecraft that strive to effect the contingent realities of the hierarchy in time and space and present them as normal and necessary to peace and security in life.

\section{Conclusion}

Curiously, the general argument about intergovernmental statecraft finds supportive evidence in the shifting context of an institutionalized site of intergovernmentality-the United Nations. In a speech on the role of the UN in a changing world, the Secretary General of the United Nations, Boutros Ghali spoke of "Enlightened multilateralism as the guarantor, not the enemy, of state sovereignty and the integrity of state," and identified the 
United Nations, "an instrument of its member states," as the agent of "Enlightened Multilateralism." ${ }^{24}$ "Member states," he further maintained, "must take on a new responsibility. They should see the United Nations as the protection of their will, not as something separate and apart." To do otherwise, Ghali cautioned, "would mean a descent into ever-deepening troubles and ultimately, chaos" at a time of unprecedented global interactions.

I want to suggest that humanitarian interventions do in fact represent activities of statist multilateralism oriented more to strategically regiment difficulties of statecraft in power politics and less to serve the needs of those who are under duress. They surely do not represent an enlightenment, a qualitative shift in ethics of governance in terms of human rights in the so called "international community" if understood as consisting of states. To paraphrase Michel Foucault, if anything, humanitarian interventions represent a dimension of a statist regime of governmentality by which men govern men. ${ }^{25}$

\section{Notes}

1. From April 1991, which marks the date of the Kurdish refugee crisis in northern Iraq, to early 1995 tens of scholarly as well as policy-oriented studies have been produced. A representative sample used in this study as cited in the paper includes: (Lewy 1992; Nanda 1992; Nafziger, 1991; Adelman, 1992; Arnison, 1993; Jackson, 1993; Fisher 1994; Rodley, 1992; Donnelly, 1993; Minear and Weiss, 1992, 1993a and 1993b; United Nations High Commissioner for Refugees (UNHCR), 1993, Frelick, 1992a,1992b, and 1993). See also Philippe Garigue. 1993. "Intervention-Sanction and 'droit d'ingérencé' International Law." International Journal, Vol. XLVIII. Ellen O'Connell. 1992. "Commentary on International Law: Continuing Limits on UN Intervention in Civil War." Indiana Law Journal, Vol. 67. Jim Whitman. 1994. "A Cautionary Note on Humanitarian Intervention." GeoJournal, Vol. 34, No. 2. Adam Roberts. 1993a . "Humanitarian War: Military Intervention and Human Rights." International Affairs, Vol. 69, No. 3. Adam Roberts. 1993b. The Road to Hell: Humanitarian Intervention." Current, Vol.
363. Jack Donnelly. 1993. "Human Rights, Humanitarian Crisis, and Intervention." International Journal, Vol. XLVIII. David Fisher. 1994. "The Ethics of Intervention."Survival, Vol. 36, No. 1.

2. Nancy D. Arnison 1993. "International Law and Non-Intervention: When Do Humanitarian Concerns Supersede Sovereignty." The Fletcher Forum of World Affairs , Vol. 17, No. 2., pp. 199-203.

3. Paul Lewis. 1992. "The Right To Intervene for a Human Cause." The New York Times, July 12, 1992, Section 4., p. 22.

4. In much the same vein, others such as Jackson (1993), Lewy (1993), an Dunn (1994) line up to articulate the negative implications of humanitarian interventions for state sovereignty. Jackson, for instance, writes that "humanitarian intervention thus seems to repudiate the norm of nonintervention itself and the international foundation of state sovereignty upon which that norm rests" (Jackson 1993, 584). See Robert H. Jackson 1993. "Armed Humanitarianism." International Journal, Vol. XLVIII. Guenter Lewy. 1993. "The Case for Humanitarian Intervention." Orbis Fall. John Dunn. 1994. "The Dilemma of Humanitarian Intervention: The Executive Power of the Law of Nature, After God." Government and Opposition, Vol. 29, No. 2.

5. L. Minear and T. G. Weiss. 1993a. Humanitarianism Across Borders: Sustaining Civilians in Times of War. Boulder and London: Lynne Reiner Publishers, p. 60. See also, Minear and Weiss. 1993b. Humanitarian Action In Times of War: A Handbook for Practitioners. Boulder and London: Lynne Reiner Publishers, p. 38-39.

6. Michel Foucault understands problematization as an art of responding to contingent difficulties and challenges of a specific practice by reconstituting these difficulties (that is, by inscribing/re-inscribing their meanings and practical/ legal content) into specific recognizable/ knowable problems which could then be acted upon within the posited framework of the practice itself. Understood as such problematizations are also productive practices, generating representational resources useful to enframing specific normality images, identities, relations, and institutions. See Michel Foucault. 1984. The Foucault Reader. Paul Rabinow (ed.) New York: Pantheon Books.

7. It is true, for example, that the intervention-the "Operation Provide Comfort" - in northern Iraq in the waning hours of the Gulf War in 1991 provided much comfort to millions, helping to save hundreds of thousand of human lives. It is also true that the intervention in Bosnia has saved and continues to save hundreds of thousands of lives. Similarly, the intervention in Somalia eased the conditions of massive starvation, which, were it not for the intervention, would have probably killed millions.

8. See L. Minear and T.G. Weiss. 1992. Groping and Coping in the Gulf Crisis: Discerning the Shape of a Humanitarian Order. World Policy Journal, Vol. IX, No. 4. Howard Adelman. 1992. "Humanitarian Intervention: the Case of the Kurds." International Journal of Refugee Law, Vol. 4 , No. 1. Ved P. Nanda. 1992. "Tragedies in Northern Iraq, Liberia, Yugoslavia, and Haiti-Revisiting the Validity of $\mathrm{Hu}$ manitarian Intervention Under International Law-Part I." Denver Journal of International Law and Policy, Vol. 20, No. 2.

9. Quoted in Lawrence Freedman and David Boren. 1992. "Safe Havens for Kurds in postwar Iraq." In Nigel Rodley (ed.). To Loose the Bands of Wickedness: International Intervention in Defense of $\mathrm{Hu}$ man Rights. Brassey's (UK): London, p. 55.

10. Ibid., p. 82.

11. National Public Radio, May 11, 1992.

12. Bill Frelick. 1992b. "The False Promise of Operation Provide Comfort: Protecting Refugees or Protecting State Power." Middle East Report, May-June. See also, Bill Frelick. 1993. “Closing Ranks: The North Locks Arms Against Refugees." In Phyllis Bennis and Michel Moushabeck (eds.) Altered States: A Reader in the New World Order. New York: Olive Branch Press. For a similar view on former Yugoslavia, see Bill Frelick. 1992a. Yugoslavia Torn Asunder: Lessons For Protecting Refugees From Civil War. Washington, D.C.: USCR (U. S. Committee For Refugees).

13. Frelick. 1992b., p. 4. In a similar fashion, Nigel Rodley speaks of "transboundary implications" as a possible "necessary" condition for undertaking humanitarian intervention. Rodley, op. cit. p. 34

14. Ali Sirmen. "Dünyada Bugün (Today In the World)" Cumhuriyet, 14 April 1991, my translation.

15. For the full text of the memorandum, see "United Nations-Republic of Iraq Memorandum of Understanding," International Journal of Refugee Law (1992) 4 (1): 113-16.

16. This imagery conjured through the memorandum and other practices run in the face of the realities "on the ground." As a Turkish columnist put it, "The border between Turkey and Iraq looks as though it disappeared. Although the border is officially closed, unofficially, it is open, as several hundred thousand people took refuge on the Turkish side already (Hasan Cemal. "Insan Bunlar Insan 
(They are Human Beings)," vCumhuriyet, April 7, 1991, my translation). The Turkish daily Cumhuriyet also reported the almost daily ministerial and ambassadorial level consultations between Turkish and Iraqi representatives. The reports indicated how the government of Iraq was an integral part of the policies devised at the time. See April 9, 10,11, of Cumhuriyet for such reports. For an extensive analysis of how the allied countries placated Iraq through the United Nations, see Rodley (1992) and Freedman and Boren (1992).

17. Kemal Kirisci. "Kürt Mülteciler ve Türkiye (Kurdish Refugees and Turkey) Cumhuriyet, 15 April 1991, my translation.

18. Yasemin Congar. "BM Derhal Irak'a Gitmeli (UN. Must Immediately Go to Iraq)" Cumhuriyet, April 24, 1991, my translation.

19. Jeff, Huysmans. 1995. “Migrants as Security Problem: Dangers of 'Securitizing' Societal Issues." In Robert Miles and Dietrich Thranhart (eds.) Migration and European Integration: The Dynamics of Inclusion and Exclusion. Madison and Teaneck: Fairliegh Dickinson University Press.

20. Richard K. Ashley. 1993. Statecraft As Mancraft. Unpublished Manuscript, p. 5-10. Jeff Huysmans, Ibid., p. 63. Hoffman, Mark. 1993. Agency, Identity and Intervention." In Ian Forbes and Mark Hoffman (eds.) Political Theory, International Relations and the Ethics of Intervention. New York: St. Martin Press, p. 202.

21. Huysmans, op. cit. p. 63.

22. Hoffman, op. cit. p. 202.

23. Ashley, op. cit. p. 9.

24. Boutros B. Ghali. "Gabriel Silver Memorial Lecture at Columbia University." SG/SM/5220, February 7, 1994.

25. Michel Foucault. 1991. "Why the Prison?" In Graham Burchell, Colin Gordon and Peter Miller (eds.) Foucault Effect: Studies in Governmentality London: Harvester Wheatsheaf.

\section{References}

Adelman, Howard. 1992. "Humanitarian Intervention: the Case of the Kurds." International Journal of Refugee Law, Vol. 4, No. 1.

Arnison, Nancy D. 1993. "International Law and Non-Intervention: When Do Humanitarian Concerns Supersede Sovereignty." The Fletcher Forum of World Affairs, Vol. 17, No. 2.

Ashley, Richard K. 1989. "Living on Border Lines: Man, Poststructuralism and War."
In International/Intertextual Relations, edited by James Der Derian and Michael Shapiro. Lexington, Mass: Lexington Books.

- 1993. Statecraft As Mancraft. Unpublished Manuscript.

Donnelly, Jack. 1993. "Human Rights, Humanitarian Crisis, and Intervention." International Journal, Vol. XLVIII.

Dunn, John. 1994. "The Dilemma of Humanitarian Intervention: The Executive Power of the Law of Nature, After God." Government and Opposition, Vol. 29, No. 2.

Fisher, David. 1994. "The Ethics of Intervention." Survival, Vol. 36, No. 1.

Foucault, Michel. 1984. The Foucault Reader, edited by Paul Rabinow. New York: Pantheon Books.

Foucault, Michel. 1991. "Why the Prison?" In Foucault Effect: Studies in Governmentality, edited by Graham Burchell, Colin Gordon, and Peter Miller. London: Harvester Wheatsheaf.

Freedman, Lawrence and Boren, David. 1992. "Safe Havens for Kurds in Postwar Iraq." In To Loose the Bands of Wickedness: International Intervention in Defense of Human Rights, edited by Nigel Rodley. Brassey's (UK): London.

Frelick, Bill. 1992a. Yugoslavia Torn Asunder: Lessons For Protecting Refugees From Civil War. Washington, D.C.: USCR (U. S. Committee For Refugees)

—. 1992b. "The False Promise of Operation Provide Comfort: Protecting Refugees or Protecting State Power." Middle East Report, May-June.

—. 1993. "Closing Ranks: The North Locks Arms Against Refugees." In Altered States: A Reader in the New World Order, edited by Phyllis Bennis and Michel Moushabeck. New York: Olive Branch Press.

Garigue, Philippe. 1993. "Intervention-Sanction and 'droit d'ingérencé' International Law." International Journal, Vol. XLVIII.

Ghali, Boutros B. 1994. "Gabriel Silver Memorial Lecture at Columbia University." SG/SM/5220, February 7.

Hoffman, Mark. 1993. Agency, Identity and Intervention." In Political Theory, International Relations and the Ethics of Intervention, edited by Ian Forbes and Mark Hoffman. New York: St. Martin Press.

Huysmans, Jeff. 1995. “Migrants as Security Problem: Dangers of 'Securitizing' Societal Issues." In Migration and European Integration: The Dynamics of Inclusion and Exclusion, edited by Robert Miles and Dietrich Thranhart. Madison and Teaneck: Fairliegh Dickinson University Press.
Jackson, Robert H. 1993. "Armed Humanitarianism." International Journal, Vol. XLVIII.

Lewis, Paul. 1992. "The Right To Intervene for a Human Cause." The New York Times, July 12, 1992, Section 4., p. 22.

Lewy, Guenter. 1993. "The Case for Humanitarian Intervention." Orbis, Fall.

Loescher, Gil. 1993. Beyond Charity: International Cooperation and the Global Refugee Crisis. Oxford: Oxford University Press.

Minear, L, and Weiss T. G. 1992. Groping and Coping in the Gulf Crisis: Discerning the Shape of a Humanitarian Order. World Policy Journal, Vol. IX, No. 4.

- 1993a. Humanitarianism Across Borders: Sustaining Civilians in Times of War. Boulder and London: Lynne Reiner Publishers.

- 1993b. Humanitarian Action In Times of War: A Handbook for Practitioners. Boulder and London: Lynne Reiner Publishers.

Nafziger, James A.R. 1991. "Self-Determination and Humanitarian Intervention in a Community of Power." Denver Journal of International Law and Policy, Vol. 20, No. 1.

Nanda, Ved P. 1992. "Tragedies in Northern Iraq, Liberia, Yugoslavia, and HaitiRevisiting the Validity of Humanitarian Intervention Under International LawPart I." Denver Journal of International Law and Policy, Vol. 20, No. 2.

O'Connell, Ellen. 1992. "Commentary on International Law: Continuing Limits on UN Intervention in Civil War." Indiana Law Journal, Vol. 67.

Reuters, August 26, 1992. "Text of Resolution 688 On Iraqi Human Rights Abuses."

Roberts, Adam. 1993a. "Humanitarian War: Military Intervention and Human Rights." International Affairs, Vol. 69, No. 3.

. 1993b. The Road to Hell: Humanitarian Intervention." Current, Vol. 363.

Rodley, Nigel (ed.). 1992. To Loose the Bands of Wickedness: International Intervention in Defense of Human Rights. Brassey's (UK): London.

Soguk, Nevzat. 1994. "Politics of Resistance and Accommodation: Managing Refugee and Immigrant Movements in the PostCold War Era." Current World Leaders: International Issues, Vol. 38, No. 2.

United Nations High Commissioner for Refugees. 1993. The State of the World's Refugees, 1993: The Challenge of Protection. New York: Penguin Books.

Whitman, Jim. 1994. "A Cautionary Note on Humanitarian Intervention." GeoJournal, Vol. 34, No. 2.

(C) Nevzat Soguk, 1996. This open-access work is licensed under a Creative Commons Attribution-NonCommercial 4.0 International License, which permits use, reproduction and distribution in any medium for non-commercial purposes, provided the original author(s) are credited and the original publication in Refuge: Canada's Journal on Refugees is cited. 